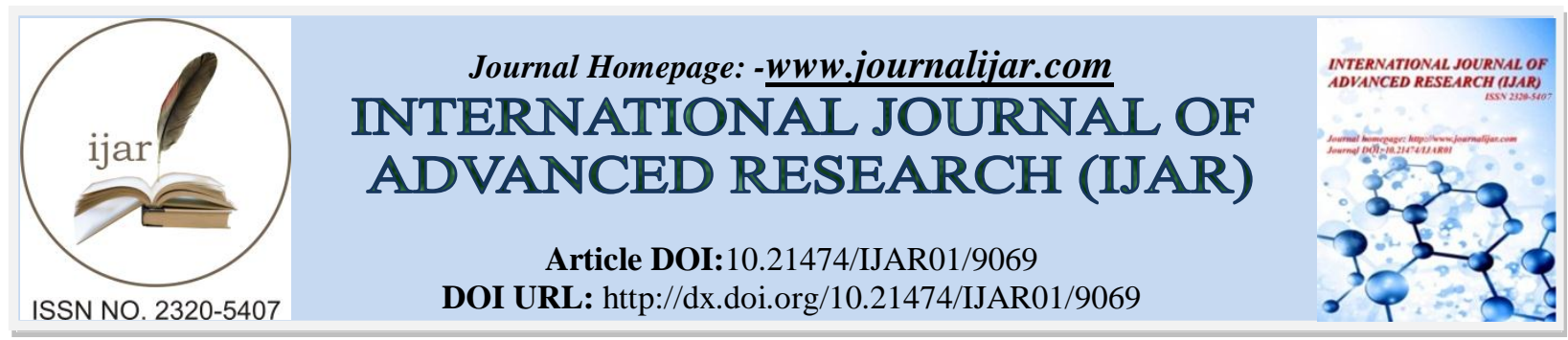

RESEARCH ARTICLE

\title{
A STUDY ON COPPER SLAG AS REPLACEMENT OF FINE AGGREGATE WITH ADDITION OF RED SOIL.
}

\section{Ms. K. Pandeeswari ${ }^{1}$, J. Kalaignanam ${ }^{2}$ And A.Kalithmohammad ${ }^{2}$.}

1. Assistant Professor, Department of Civil Engineering, Sethu Institute of Technology, Virudhunagar.

2. UG student, Department of Civil Engineering, Sethu Institute of Technology, Virudhunagar.

\section{Manuscript Info}

Manuscript History

Received: 15 March 2019

Final Accepted: 17 April 2019

Published: May 2019

Key words:-

Copper slag, Red soil.

\begin{abstract}
This paper reports an experimental program to investigate the effect of using copper slag as a complete $100 \%$ replacement of sand on the property of fine aggregate. Addition of red soil in ratio $0 \%, 5 \%, 10 \%$ in cement.M25 mix design has been used. Concrete mixes were evaluated for compressive strength and split tensile strength. With two different composition of 7 days and 28 days. This result indicates that the $10 \%$ addition of red soil to cementand 100\% replacement of copper slag show the greater results in both split tensile strength and compressive strength than compared to the conventional concrete. Whereas the addition of 5\% red soil to cement causes the result in reduction of compressive strength and split tensile strength, however it shows the greater result when compared to the conventional concrete.
\end{abstract}

Copy Right, IJAR, 2019,. All rights reserved.

\section{Introduction:-}

In modern world there is speedy growth of development in the construction due to this large amount of natural resources is been destroyed by clearing and dumping the surface so the natural resources are been depleting worldwide. At the same time waste from the industries are increasing significantly. The sustainable development for construction involves a use of non-conventional and inventive materials and recycling of waste material. In order to dump them and throw it to affect the natural resources and to find the alternative ways for conserving the environment aggregates are been considered as one of the main ingredient of concrete. In order to reduce demand on natural aggregate as the main source of aggregate in concrete, artificially manufactured aggregate and waste from industrial provides alternative way for construction industry. Utilization of aggregate from industrial waste can be alternate to the natural and artificial aggregate.

For many years there is a research for the replacing the construction material, such as fine aggregate by copper slag. Similarly the research has been published with regret to material such as coal, fly ash, copper slag and silica fumes. Copper slag is an abrasive blasting grit (by-product) made of granulated slag from metal smelting process and refining of copper in which sulphur dioxide is released.

To produce every ton of copper approximately $2.2-3.0$ ton of cols are generated.

Corresponding Author:-Ms. K. Pandeeswari.

Address:-Assistant Professor, Department of Civil Engineering, Sethu Institute of Technology, 
This would also lead additional benefits in terms of reduction in cost, energy saving promoting ecological balance and conservation of natural resources. Thus the research was performed to evaluate the potential use of copper slag as sand replacing.

\section{Material:-}

\subsection{Cement}

The cement used in this study was Portland pozzolana cement from Ramco cements.

\subsection{Fine Aggregates}

Fine aggregate of $10 \mathrm{~mm}$ fine $\mathrm{m}$-sand from Madurai region.

\subsection{Copper Slag}

Copper slag is the byproduct material produced from the process of manufacturing copper. The copper slag used here is been bought from the Thoothukudi Sterlite.

\subsection{Red soil}

$10 \mathrm{~mm}$ fine red soil is been used.

\subsection{Coarse Aggregate}

Coarse aggregate used in this are size of $15 \mathrm{~cm}$. It is from original bed rocks. They are available in different irregular shape. It should be free from organic impurity dirt content.

\section{Laboratory Testing Program}

\subsection{Mix design and sample preparation}

The concrete mixtures have been made with $100 \%$ replacement of copper slag and partial replacement of red soil in cement as $0 \%, 5 \%$, and $10 \%$. First the constituents are weight according to the $\mathrm{m} 25 \mathrm{mix}$ ratio in separate bucket. Over all time taken for mixing the concrete was about 5 min. The mix was been completely tamped in specimen and filled with tamping rod. The specimens were remolded after $24 \mathrm{hrs}$ cured in water and then tested in room temperature at required ages.

\subsection{Experimental work}

\subsubsection{Sieve analysis}

The experimental work starts with the sieve analysis. IS specified sieves of varying sizes are used as shown in table 3.1 .

Table 3.1:-Sieve analysis of Fine Aggregate

\begin{tabular}{|c|c|c|c|c|c|c|}
\hline Sieve size & $\begin{array}{c}\text { Empty } \\
\text { weight of } \\
\text { sieve }\end{array}$ & $\begin{array}{c}\text { Retained } \\
\text { weight of } \\
\text { sieve }\end{array}$ & $\begin{array}{c}\text { Retained } \\
\text { weight of soil }\end{array}$ & $\begin{array}{c}\text { Cumulative } \\
\text { weight } \\
\text { retained }\end{array}$ & $\begin{array}{c}\text { Cumulative } \\
\text { \% retained }\end{array}$ & \% finer \\
\hline 4.75 & 367 & 382 & 15 & 15 & 1.5 & 98.5 \\
\hline 2.36 & 346 & 426 & 80 & 95 & 9.5 & 90.5 \\
\hline 1.18 & 345 & 698 & 353 & 448 & 44.8 & 55.2 \\
\hline 1 & 363 & 466 & 103 & 551 & 55.1 & 44.9 \\
\hline 600 & 298 & 350 & 52 & 603 & 60.3 & 39.7 \\
\hline 300 & 300 & 469 & 169 & 772 & 77.2 & 22.8 \\
\hline 150 & 309 & 490 & 181 & 953 & 95.3 & 4.7 \\
\hline pan & 300 & 347 & 47 & 1000 & 100 & 0 \\
\hline
\end{tabular}

Fineness Modulus of Sand = 2.73

\subsubsection{Physical Properties of Materials}

By physical properties analysis the copper slag has a specific gravity of 3.6, which is higher than that for sand of 2.55, and OPC of 3.15. It can results in higher density when used as sand substitution. It is expected that the free water content in concrete matrix will increase as the copper slag content increases which consequently will lead to increase in the workability of the concrete. 


\subsection{Compressive strength}

While testing the compressive strength addition of red soil to the cement of $10 \%$ shows the greater the result than compared to conventional concrete. $5 \%$ and $10 \%$ of red soil and replacement of copper slag as shown in table 3.3

Table 3.3:-Compressive Strength of Concrete With 5\% \& 10\% Replacement of Red Soil

\begin{tabular}{|c|c|c|c|c|}
\hline S.No. & $\begin{array}{c}\text { Conventional } \\
\text { Concrete }\end{array}$ & 0\%Red soil 100\%COSL & $\begin{array}{c}\text { 5\% Red Soil } \\
\text { 100\% COSL }\end{array}$ & $\begin{array}{c}\text { 10\% Red soil } \\
\text { 100 \% COSL }\end{array}$ \\
\hline 1. & 17.4 & 20.07 & 21.5 & 23.38 \\
\hline 2. & 15.54 & 20.68 & 22.4 & 25.74 \\
\hline 3. & 15.83 & 21.8 & 22.8 & 19.98 \\
\hline Average & $\mathbf{1 6 . 2 6}$ & $\mathbf{2 0 . 8 5}$ & $\mathbf{2 2 . 2 3}$ & $\mathbf{2 3 . 0 3}$ \\
\hline
\end{tabular}

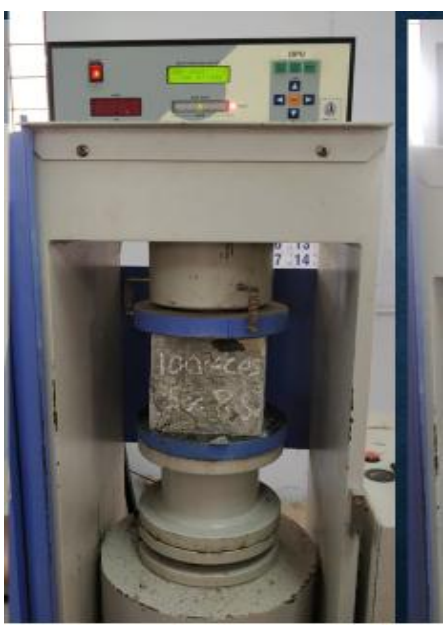

Fig 3.3.1:-Compressive Strength Testing

\subsection{Split tensile strength}

While testing the split tensile strength addition of red soil to the cement of $10 \%$ shows the greater the result than compared to conventional concrete. $5 \%$ and $10 \%$ of red soil and replacement of copper slag as shown in table 3.5

Table 3.5:-Split Tensile Strength of Concrete With5\% \& 10\%Replacement of Red Soil 7 days

\begin{tabular}{|c|c|c|c|c|}
\hline S.No. & $\begin{array}{c}\text { Conventional } \\
\text { Concrete }\end{array}$ & $\begin{array}{c}\mathbf{0 \%} \text { Red soil } \\
\mathbf{1 0 0 \%} \text { COSL }\end{array}$ & $\begin{array}{c}\text { 5\% Red Soil } \\
\mathbf{1 0 0 \%} \text { COSL }\end{array}$ & $\begin{array}{c}\mathbf{1 0 \%} \text { Red soil } \\
\mathbf{1 0 0} \% \text { COSL }\end{array}$ \\
\hline 1. & 1.57 & 1.98 & 1.85 & 2.01 \\
\hline 2. & 1.74 & 2.02 & 1.83 & 1.91 \\
\hline 3. & 1.71 & 2.01 & 1.86 & 2.15 \\
\hline Average & $\mathbf{1 . 6 7}$ & $\mathbf{2 . 0 0}$ & $\mathbf{1 . 8 5}$ & $\mathbf{2 . 0 2}$ \\
\hline
\end{tabular}

Fig 3.4.1:-split tensile strength testing

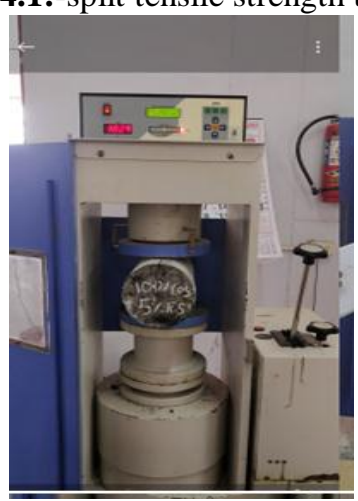




\section{Results and Discussion:-}

4.1 Compressive Strength

Addition of red soil. to the cement of $10 \%$ shows the greater the result than compared to conventional concrete.

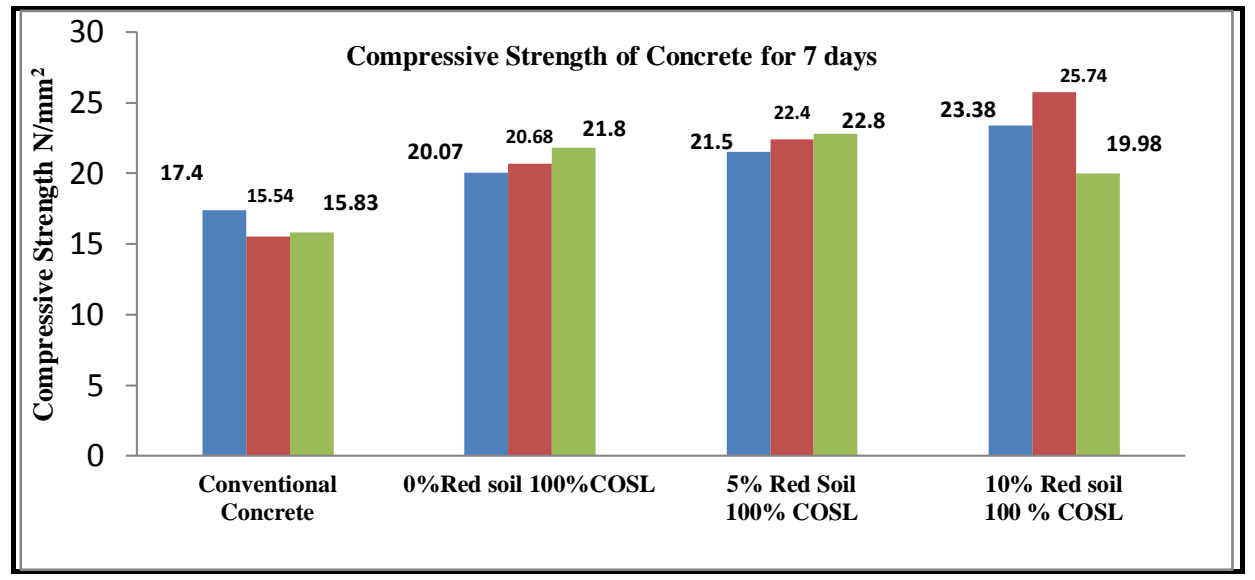

\subsection{Split tensile strength}

Fig. 4.1:-Compressive strength of Concrete for 7 days

Split tensile strength it showed the result with higher percentage for $10 \%$ of red soil and $100 \%$ replacement when compared to the conventional concrete

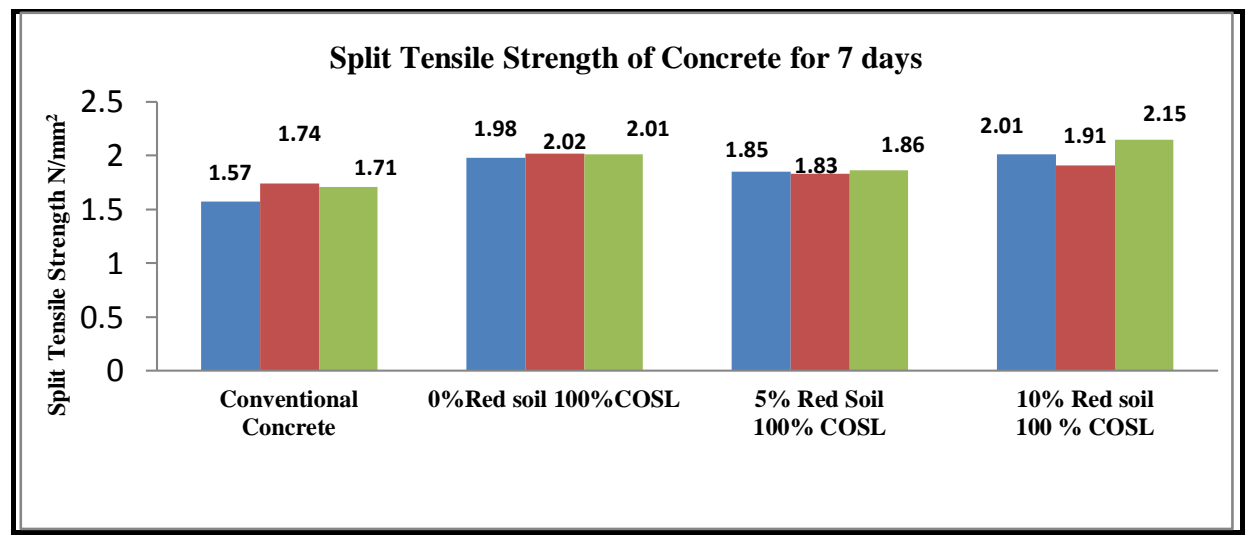

\section{Conclusion:-}

Fig. 4.2:-Split Tensile Strength of Concrete for 7 days

The following conclusion is drawn from the study that the

1. The maximum compressive strength is been obtained while adding $10 \%$ of red soil to the $100 \%$ replacement of copper slag, thus the Concrete gain more strength than conventional concrete.

2. It is observed that all percentage replacement of fine aggregate by copper slag the compressive strength of concrete is more than conventional concrete.

3. The compressive strength and split tensile strength is increased due to high toughness of copper slag.

4. It is recommended that $10 \%$ addition of red soil to $100 \%$ replacement of copper slag can be used as it has good properties. 


\section{References:-}

1. Dhanalakshmi.S, Mangaiyarkarasi.A, Bavani.S, Anusha. D, Kumar. A, "Experimental Study on Partial Replacement of Fine Aggregate with Quarry Dust and Red Soil in Concrete" International Journal of Engineering and Technology Research (IJSETR), Volume 7, Issue 3, March 2018.

2. Ambrish.E, Dhavamani Doss. S, ShanmugaNathan, N, Ganapathi Raj "Partial Replacemetn of Copper Slag as Fine aggregate" SSRG International Jouranl of Civil Engineering (SSRG - IJCE) Volume 4 Issue 3 March 2017

3. M. Vinoth Kumar, K. Pandeeswari, "Experimental Investigation on Engineering Properties of Red mud" International Jouranl of Innovative Research in Science, Engineering and Technology, Vol.6, Issue 5, May 2017

4. N. Sreenivasulu, A. Roopa, M. Venkateswarlu, P.Pavani, "A case Stusy on Copper Slag as Replacement of Fine Aggregate" International Research Journal of Engineering and Technology (IRJET), Volume 3, Issue 7 - July 2016

5. Zine Kiran Sambhaji, Prof. Pankaj B, Autade, "Effect of Copper slag as a Fine Aggregate on Properties of Concrete" International Research Journal of Engineering and Technology, Volume 3, Issue 6 - June 2016

6. James Alexanders, Antony Godwin, S Alexander, "Study on the Behaviour of Red soil cement Concrete" International Journal of advances in Mechanical and Civil Engineering, Volume 3, Issue 3 - June 2016

7. M.V.Patil, "A study on Properties and effects of Copper Slag in Concrete" International Journal of Mechanical and Production Engineering, Volume 3, Issue 3 - March 2015

8. Caliskan S, Behnood A. Recycling copper slag as coarse aggregate: hardened properties of concrete. In: Proceedings of 7th international conference on concrete technology in developing countries; 2004. p. 91-8.

9. Zong L. The replacement of granulated copper slag for sand concrete. J Qingdao Inst Architect Eng 2003;24(2):20-2.

10. AS Alnuaimi(2012), "Effects of Copper Slag as a Ultimate Strength of Reinforced Concrete Slender

Replacement for Aggregate on the Behavior and Columns",SultanQaboos University,Vol.9,pp.90-102.

11. Brindha D.,Baskaran. T,Nagan.S (2010), "Assessment of Corrosion and Durability Characteristics of Copper Slag Admixed Concrete", International Journal Of Civil And Structural Engineering Vol 1, No 2, pp- 192-211.

12. Khalifa S. Al-Jabri, Abdullah H. Al-Saidy, RamziTaha (2011), "Effect of copper slag as a fine aggregate on the concrete", Construction and Building Materials,Vol. 25. 